\title{
Further Cytotoxic Sesquiterpene Lactones from Elephantopus mollis KUNTH
}

\author{
Turibio Kuiate TABopda, ${ }^{*, a, b}$ Joseph Ngoupayo, ${ }^{a}$ Jiawei Liu,${ }^{b}$ Muhammad Shaiq Ali, ${ }^{c}$ \\ Shamsun Nahar KHAN, ${ }^{c}$ Bonaventure Tchaleu NGADJUI, ${ }^{a}$ and Bang LuU ${ }^{b}$ \\ ${ }^{a}$ Département de Chimie Organique, Université de Yaoundé I; BP 812 Yaoundé, Cameroun: ${ }^{b}$ Laboratoire de Chimie \\ Organique des Substances Naturelles, UMR 7177 CNRS-Université Louis Pasteur; 5 Rue Blaise Pascal, F-67084 \\ Strasbourg, France: and ${ }^{c}$ H.E.J. Research Institute of Chemistry, University of Karachi; Karachi-75270, Pakistan. \\ Received October 2, 2007; accepted October 15, 2007; published online November 8, 2007
}

Three new sesquiterpene lactones, $(4 \beta H)-5 \alpha$-hydroxy-8 $\alpha$-(2-methylbut-2-enoyloxy)-2-oxo-1(10),11(13)-guaiadien-12,6 $\alpha$-olide (1), $(4 \beta H)-8 \alpha$-(2-methylbut-2-enoyloxy)-2-oxo-1(5),10(14),11(13)-guaiatrien-12,6 $\alpha$-olide (2) and 2,5-epoxy-2 $\beta$-hydroxy-4 $\alpha$-methoxy-8 $\alpha$-(2-methylbut-2-enoyloxy)-4(15),10(14),11(13)-germacratrien-12,6 $\alpha$ olide (3), have been isolated from roots and stems of Elephantopus mollis together with two known sesquiterpene lactones $(4,5)$. The identification of the isolates was accomplished by spectroscopic methods. Compounds $(1-5)$ exhibited significant cytotoxic activities against mouse neuroblastoma B104 cells.

Key words neuroblastoma; sesquiterpene lactone; Elephantopus mollis

Elephantopus mollis KunTH, belonging to the Asteraceae, is used in Cameroon for the treatment of cancer, fracture, abdominal pains, defective lactation and snake bite. ${ }^{1)}$ In our continuing search for novel bioactive compounds from Cameroon medicinal plants, we have previously isolated sesquiterpene lactones with cytotoxic activities. ${ }^{2}$ Sesquiterpene lactones have been isolated from numerous genera of the Asteraceae family and are described as the active constituents of a variety of medicinal plants used in traditional medicine. ${ }^{3-7)}$ Because of an interest in cytotoxic sesquiterpene lactones, the methanol extract of roots and stems of $E$. mollis was re-examined and three new cytotoxic sesquiterpene lactones, namely, $(4 \beta H)-5 \alpha$-hydroxy- $8 \alpha$-(2-methylbut-2-enoyloxy)-2-oxo-1(10),11(13)-guaiadien-12,6 $\alpha$-olide (1), $(4 \beta H)-8 \alpha-(2$-methylbut-2-enoyloxy)-2-oxo1(5),10(14),11(13)-guaiatrien-12,6 $\alpha$-olide (2) and 2,5epoxy-2 $\beta$-hydroxy- $4 \alpha$-methoxy- $8 \alpha$-(2-methylbut-2-enoyloxy)-4(15),10(14),11(13)-germacratrien-12,6 $\alpha$-olide (3) were isolated, together with $2 \beta$-methoxy-2-deethoxyphantomolin (4), $\left.{ }^{8}\right) 2 \beta$-methoxy-2-deethoxy-8-O-deacylphantomolin-8-O-tiglinate $(\mathbf{5}){ }^{8}{ }^{8}$ molephantin and molephantinin. ${ }^{2)}$ These compounds were evaluated for their cytotoxic activities against neuroblastoma B104.

\section{Results and Discussion}

The chloroform extract, which was obtained from methanol extract of the whole bodies of E. mollis, was subjected to repeated column chromatography followed by preparative thin-layer chromatography (TLC) to give three new $(\mathbf{1}-\mathbf{3})$ and two known $(\mathbf{4}, \mathbf{5})$ compounds.

Compound $\mathbf{1}$ was assigned the molecular formula $\mathrm{C}_{20} \mathrm{H}_{24} \mathrm{O}_{6}$ by HR-ESI-MS $\left(\mathrm{m} / \mathrm{z} 361.1651\right.$ for $\left.[\mathrm{M}+\mathrm{H}]^{+}\right)$. The IR spectrum suggested the presence of a hydroxyl group $\left(3472 \mathrm{~cm}^{-1}\right)$, an $\alpha, \beta$-unsaturated ester carbonyl $\left(1715 \mathrm{~cm}^{-1}\right)$ and a lactone carbonyl group $\left(1772 \mathrm{~cm}^{-1}\right)$. The ${ }^{1} \mathrm{H}-$ and ${ }^{13} \mathrm{C}-$ NMR data (Table 1) revealed the presence of a ketone carbonyl $\left(\delta_{\mathrm{C}} 204.0\right)$, an $\alpha$-methylene- $\gamma$-butyrolactone moiety $\left[\delta_{\mathrm{H}} 5.52,6.01\left(\mathrm{CH}_{2}\right) ; \delta_{\mathrm{C}} 121.1\left(\mathrm{CH}_{2}\right), 138.9(\mathrm{C}), 169.1\right.$ (carbonyl)] and a 2-methylbut-2-enoyloxy moiety $\left[\delta_{\mathrm{H}} 6.88(\mathrm{CH})\right.$, 1.65 and $1.83\left(2 \mathrm{CH}_{3}\right) ; \delta_{\mathrm{C}} 165.6$ (carbonyl), $128.5(\mathrm{C}), 138.5$
$(\mathrm{CH}), 12.2$ and $\left.14.7\left(2 \mathrm{CH}_{3}\right)\right]$. In addition, signals of a tetrasubstituted olefin $\left(\delta_{\mathrm{C}} 136.9,151.9\right)$, a quaternary oxygenated carbon $\left(\delta_{\mathrm{C}} 78.0\right)$, four methine carbons two of which were oxygenated $\left(\delta_{\mathrm{C}} 85.9,71.4\right)$, two methylene carbons $\left(\delta_{\mathrm{C}} 46.7\right.$, $43.8)$ and two methyl groups $\left(\delta_{\mathrm{C}} 15.1,23.2\right)$ were observed. The connectivity from H-6 to H-9 was confirmed by COSY spectroscopy. Analysis of 2D NMR data (COSY, heteronuclear single quantum correlation (HSQC), HMBC) led to the complete assignment of NMR signals. HMBC correlations of $\mathrm{H}_{3}-15$ to $\mathrm{C}-3, \mathrm{C}-4$ and $\mathrm{C}-5$ and from $\mathrm{H}_{3}-14$ to $\mathrm{C}-1, \mathrm{C}-9$, and $\mathrm{C}-10$ revealed that $\mathrm{Me}-14$ and $\mathrm{Me}-15$ are attached to $\mathrm{C}-10$ and $\mathrm{C}-4$, respectively. Further HMBC correlations were observed between $\mathrm{H}_{2}-3$ and $\mathrm{C}-1, \mathrm{C}-2, \mathrm{C}-4$ and $\mathrm{C}-5$ and suggested that compound $\mathbf{1}$ is a guaiane-type sesquiterpene. The configuration at C-4, C-5, C-6, C-7, and C-8 was determined by NOESY (correlations between $\mathrm{H}-4$ and $\mathrm{H}-6, \mathrm{H}-6$ and $\mathrm{H}-8$, $\mathrm{H}-7$ and $\mathrm{H}-9 \mathrm{a}$ were observed) and by comparison of coupling constants with those of naturally occurring germacranolide and guaiane-type sesquiterpenes. ${ }^{10-12)}$ Further confirmation of the structure was made by comparison of data with those of $(4 \beta H)-5 \alpha$-hydroxy-8 $\alpha$-(2-methylpropenoyloxy)$1(10), 11(13)$-guaiadien-12,6 $\alpha$-olide. ${ }^{3)}$ The relative configuration of the 2-methylbut-2-enoyloxy residue was deduced from coupling constants (Table 1) and by NOE data obtained from NOESY spectrum (Fig. 1).

Compound 2 was shown to have the molecular formula $\mathrm{C}_{20} \mathrm{H}_{22} \mathrm{O}_{5}$ by HR-ESI-MS $\left(m / z \quad 343.1549[\mathrm{M}+\mathrm{H}]^{+}\right)$. The IR spectrum indicated the presence of an $\alpha, \beta$-unsaturated ester carbonyl $\left(1708 \mathrm{~cm}^{-1}\right)$ and a lactone carbonyl group $\left(1769 \mathrm{~cm}^{-1}\right)$. The ${ }^{1} \mathrm{H}-$ and ${ }^{13} \mathrm{C}$-NMR data (Table 1$)$ were similar to those of 1 with a ketone carbonyl, an $\alpha$-methylene- $\gamma$ butyrolactone and a 2-methylbut-2-enoyloxy moiety. However, the quaternary oxygenated carbon observed in compound 1 is replaced by an exomethylene group $\left[\delta_{\mathrm{H}}\right.$ $\left.5.24,5.75 ; \delta_{\mathrm{C}} 122.2\left(\mathrm{CH}_{2}\right), 133.5(\mathrm{C})\right]$. Since an olefin carbon $\left[\delta_{\mathrm{C}} 174.6(\mathrm{C})\right]$ was shifted downfield, it was thought to be located at the $\beta$ position of a conjugated system with a carbonyl group. This was confirmed by the HMBC correlations between $\mathrm{H}-4$ and C-1, C-2, C-3, C-5 and C-6. Structure of 2 was established by comparing NMR data with those of 
Table 1. ${ }^{1} \mathrm{H}$ - and ${ }^{13} \mathrm{C}-\mathrm{NMR}$ Data of Compounds $\mathbf{1}-\mathbf{3}$ in $\mathrm{CDCl}_{3}(J$ Values $(\mathrm{Hz})$ in Parentheses)

\begin{tabular}{|c|c|c|c|c|c|c|}
\hline \multirow{2}{*}{ Position } & \multicolumn{2}{|r|}{1} & \multicolumn{2}{|r|}{2} & \multicolumn{2}{|r|}{3} \\
\hline & ${ }^{13} \mathrm{C}$ & ${ }^{1} \mathrm{H}$ & ${ }^{13} \mathrm{C}$ & ${ }^{1} \mathrm{H}$ & ${ }^{13} \mathrm{C}$ & ${ }^{1} \mathrm{H}$ \\
\hline 1 & 136.9 & & 138.5 & & 51.8 & $\begin{array}{l}2.46(\mathrm{dd}, 14,1) \\
2.52(\mathrm{dd}, 14,1)\end{array}$ \\
\hline 2 & 204.0 & & 206.4 & & 107.1 & \\
\hline 3 & 46.7 & $\begin{array}{l}2.11(\mathrm{dd}, 17,13) \\
2.27(\mathrm{dd}, 17,9)\end{array}$ & 46.0 & $\begin{array}{l}2.15(\mathrm{dd}, 19,1) \\
2.81(\mathrm{dd}, 19,7)\end{array}$ & 45.4 & $\begin{array}{l}2.00(\mathrm{dd}, 14,1) \\
2.64(\mathrm{dd}, 14,1)\end{array}$ \\
\hline 4 & 37.0 & $2.37(\mathrm{~m})$ & 35.3 & $3.24(\mathrm{qdd}, 7,7,1)$ & 83.8 & \\
\hline 5 & 78.0 & & 174.6 & & 85.9 & $4.38(\mathrm{~d}, 4)$ \\
\hline 6 & 85.9 & $4.25(\mathrm{~d}, 10)$ & 78.6 & $5.53(\mathrm{~d}, 10)$ & 79.4 & $4.16(\mathrm{dd}, 6,4)$ \\
\hline 7 & 47.1 & $3.90(\mathrm{~m})$ & 50.3 & $3.50(\mathrm{~m})$ & 39.9 & $3.77(\mathrm{~m})$ \\
\hline 8 & 71.4 & $5.01(\mathrm{ddd}, 10,10,2)$ & 75.1 & $5.38(\mathrm{ddd}, 9,4,4)$ & 75.4 & $5.06(\mathrm{ddd}, 10,3,2)$ \\
\hline 9 & 43.8 & $\begin{array}{l}2.28(\mathrm{dd}, 13,2) \\
3.05(\mathrm{dd}, 13,10)\end{array}$ & 41.6 & $\begin{array}{l}2.61(\mathrm{dd}, 15,4) \\
2.86(\mathrm{dd}, 15,7)\end{array}$ & 34.3 & $\begin{array}{l}2.63(\mathrm{dd}, 16,2) \\
2.72(\mathrm{dd}, 16,3)\end{array}$ \\
\hline 10 & 151.9 & & 133.5 & & 140.3 & \\
\hline 11 & 138.9 & & 138.3 & & 136.4 & \\
\hline 12 & 169.1 & & 169.8 & & 169.4 & \\
\hline 13 & 121.1 & $\begin{array}{l}5.52(\mathrm{~d}, 3) \\
6.01(\mathrm{~d}, 3)\end{array}$ & 122.6 & $\begin{array}{l}5.58(\mathrm{~d}, 3) \\
6.14(\mathrm{~d}, 3)\end{array}$ & 124.6 & $\begin{array}{l}5.71(\mathrm{dd}, 3,1) \\
6.21(\mathrm{dd}, 3,1)\end{array}$ \\
\hline 14 & 23.2 & $2.18(\mathrm{~s})$ & 122.2 & $\begin{array}{l}5.24(\mathrm{~d}, 2) \\
5.75(\mathrm{~d}, 2)\end{array}$ & 121.7 & $\begin{array}{l}5.20(\mathrm{brs}) \\
5.37(\mathrm{brs})\end{array}$ \\
\hline 15 & 15.1 & $1.15(\mathrm{~d}, 7)$ & 21.8 & $1.35(\mathrm{~d}, 7)$ & 26.0 & $1.35(\mathrm{~s})$ \\
\hline $1^{\prime}$ & 165.6 & & 165.3 & & 166.0 & \\
\hline $2^{\prime}$ & 128.5 & & 128.5 & & 128.4 & \\
\hline $3^{\prime}$ & 138.5 & $6.88(\mathrm{dq}, 7,2)$ & 138.6 & $6.95(\mathrm{dq}, 7,2)$ & 138.6 & $6.96(\mathrm{dq}, 7,2)$ \\
\hline $4^{\prime}$ & 12.2 & $1.83(\mathrm{dq}, 2,2)$ & 12.4 & $1.87(\mathrm{dq}, 2,2)$ & 12.2 & $1.90(\mathrm{dq}, 2,2)$ \\
\hline $5^{\prime}$ & 14.7 & $1.65(\mathrm{dq}, 7,2)$ & 14.8 & $1.62(\mathrm{dq}, 7,2)$ & 14.6 & $1.61(\mathrm{dq}, 7,2)$ \\
\hline $\mathrm{OMe}$ & & & & & 51.8 & $3.12(\mathrm{~s})$ \\
\hline
\end{tabular}<smiles>CC=C(C)C(=O)O[C@H]1CC(C)=C2C(=O)C[C@H](C)[C@]2(O)C(O)C(=O)C1=S</smiles><smiles>C=C1C[C@H](OC(=O)/C(C)=C/C)C2C(=C)C(=O)O[C@@H]2C2=C1C(=O)C[C@H]2C</smiles>

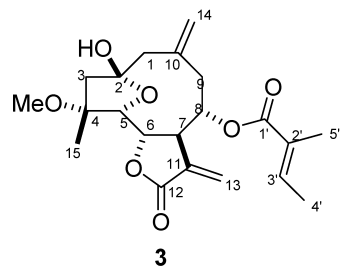

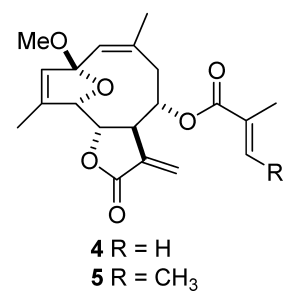

Fig. 1. Chemical Structures of Compounds $\mathbf{1}-\mathbf{5}$

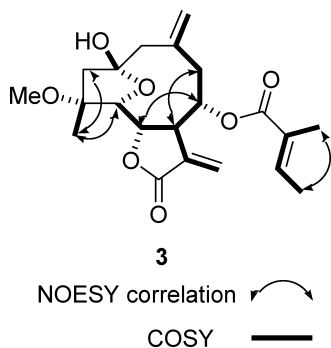

Fig. 2. Key COSY and Observed NOESY Correlations for Compound 3

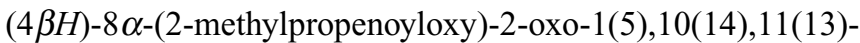
guaiatrien-12,6 $\alpha$-olide isolated from the same plant. $^{2)}$

The molecular formula of compound 3 was determined to be $\mathrm{C}_{21} \mathrm{H}_{28} \mathrm{O}_{7}$ by the HR-ESI-MS ( $\mathrm{m} / z$ 393.1917 $\left.[\mathrm{M}+\mathrm{H}]^{+}\right)$,
Table 2. Cytotoxic Activity of Compounds $\mathbf{1}-\mathbf{5}$ against Neuroblastoma B104

\begin{tabular}{cc}
\hline \hline Compound & $\mathrm{IC}_{50}(\mu \mathrm{M})$ \\
\hline $\mathbf{1}$ & 1.93 \\
$\mathbf{2}$ & 2.13 \\
$\mathbf{3}$ & 1.58 \\
$\mathbf{4}$ & 2.57 \\
$\mathbf{5}$ & 3.85 \\
\hline
\end{tabular}

${ }^{13} \mathrm{C}-\mathrm{NMR}$ and ${ }^{13} \mathrm{C}$ DEPT NMR analyses. The IR spectrum showed a strong broad hydroxyl band $\left(3544 \mathrm{~cm}^{-1}\right)$, an $\alpha, \beta$ unsaturated ester carbonyl $\left(1718 \mathrm{~cm}^{-1}\right)$ and a lactone carbonyl group $\left(1781 \mathrm{~cm}^{-1}\right)$. Comparison of NMR spectra with those of 1 and 2 suggested the absence of unsaturated carbonyl in 3 , but the presence of an acetal carbon $\left(\delta_{\mathrm{C}} 107.1\right)$. In the HMBC spectrum, cross peaks were observed between $\mathrm{C}-2, \mathrm{H}-1, \mathrm{H}-3$ and $\mathrm{H}-5$ respectively, indicating that acetal carbon was situated at C-2. Compound 3 was assumed to be a germacranolide-type sesquiterpene with ether linkage between $\mathrm{C}-2$ and $\mathrm{C}-5$. The ${ }^{1} \mathrm{H}$ - and ${ }^{13} \mathrm{C}-\mathrm{NMR}$ indicated the presence of an $\alpha$-methylene- $\gamma$-butyrolactone moiety $\left[\delta_{\mathrm{H}}\right.$ 5.71, $6.21\left(\mathrm{CH}_{2}\right) ; \delta_{\mathrm{C}} 124.6\left(\mathrm{CH}_{2}\right), 136.4(\mathrm{C}), 169.4$ (carbonyl)], a 2-methylbut-2-enoyloxy moiety $\left[\delta_{\mathrm{H}} 6.96(\mathrm{CH})\right.$, 1.61 and $1.90\left(2 \mathrm{CH}_{3}\right) ; \delta_{\mathrm{C}} 166.0$ (carbonyl), $128.4(\mathrm{C}), 138.6$ $(\mathrm{CH}), 12.2$ and $\left.14.6\left(2 \mathrm{CH}_{3}\right)\right]$, an exomethylene $\left[\delta_{\mathrm{H}} 5.20\right.$, $\left.5.37\left(\mathrm{CH}_{2}\right) ; 121.7\left(\mathrm{CH}_{2}\right), 140.3(\mathrm{C})\right]$ and a methoxyl group $\left(\delta_{\mathrm{H}} 3.12 ; \delta_{\mathrm{C}} 51.8\right)$. The disposition of the methoxyl group was determined by the analysis of the NOESY spectra. Analysis of the ${ }^{1} \mathrm{H}$ - and ${ }^{13} \mathrm{C}-\mathrm{NMR}$ data, HMBC, HSQC and NOESY spectrum provided evidence that 3 possesses the same skeleton and stereochemistry as 2,5-epoxy-2 $\beta$-hy- 
droxy-8 $\alpha$-(2-methylbut-2-enoyloxy)-4(15),10(14),11(13)germacratrien-12,6 $\alpha$-olide recently isolated from E. mollis. ${ }^{2}$

The antiproliferative effects of these isolated compounds were evaluated in vitro, against neuroblastoma B104 by using the sulforhodamine B assay. ${ }^{9}$ The five sesquiterpene lactones 1-5 exhibited significant cytotoxic activities (Table 2).

\section{Experimental}

General IR spectra were obtained with a Nicolet AVATAR 320 FT-IR spectrophotometer. ${ }^{1} \mathrm{H}-\mathrm{NMR},{ }^{13} \mathrm{C}-\mathrm{NMR}, \mathrm{DEPT}, \mathrm{COSY}, \mathrm{NOESY}, \mathrm{HSQC}$ and HMBC experiments were performed on a Bruker Avance DPX instrument $\left(300 \mathrm{MHz}\right.$ for ${ }^{1} \mathrm{H}$ and $75 \mathrm{MHz}$ for ${ }^{13} \mathrm{C}$ ). All chemical shifts were given in $\mathrm{ppm}$, with tetramethylsilane as an internal standard. Optical rotations were recorded on a Perkin-Elmer 241 polarimeter. UV spectra were recorded on a Bio-TeK spectrophotometer. Silica gel 60 F254 (Merk) was used for TLC. Mass spectra were recorded on a Bruker Daltonics microTOF mass spectrometer.

Plant Material The roots and stems of E. mollis were collected from Ebolowa in the southern province of Cameroon and identified by Dr. Tchiengue Barthelemy of the National Herbarium of Cameroon where a voucher specimen $\left(\mathrm{N}^{\circ} 48561\right)$ is deposited

Extraction and Isolation Air-dried whole plant ( $300 \mathrm{~g})$ of E. mollis was extracted with methanol $(21 \times 3)$ at room temperature. The solvent was evaporated in vacuum to yield a dark residue. The residue was suspended in $\mathrm{H}_{2} \mathrm{O}$ and extracted with $\mathrm{CHCl}_{3}$ and $25 \mathrm{~g}$ of extract were obtained. Part of the crude extract $(15 \mathrm{~g})$ was dissolved in $\mathrm{MeOH}$ and mixed with silica gel, dried at room temperature, and subjected to vacuum liquid chromatography (VLC) on silica gel $(40-63 \mu \mathrm{m}, 9 \times 73 \mathrm{~cm})$ using a step-gradient of $\mathrm{CHCl}_{3}-\mathrm{AcOEt}$. Ten fractions (A: $10: 0 ; \mathrm{B}: 9: 1 ; \mathrm{C}: 8: 2 ; \mathrm{D}: 7: 3 ; \mathrm{E}: 6: 4 ; \mathrm{F}$ : $5: 5 ; \mathrm{G}: 4: 6 ; \mathrm{H}: 3: 7 ; \mathrm{I}: 2: 8 ; \mathrm{J}: 0: 10$; each $2 \times 250 \mathrm{ml}$ ) was obtained on the basis of TLC analysis. All the fractions were subjected to a cytotoxicity test on neuroblastoma B104, and only D, E and F showed appreciable activities $\left(\mathrm{IC}_{50} 7.85,5.32,13.63 \mu \mathrm{g} / \mathrm{ml}\right.$, respectively). Fraction D (820 mg) was crystallized from $\mathrm{MeOH}$ to give molephantin $(315 \mathrm{mg}$ ) and molephantinin $(148 \mathrm{mg})$. Fraction E (132 mg) was chromatographed over Sephadex LH-20 with $\mathrm{MeOH}$ as eluent to give three main subfractions (E1, E2, E3). Fraction E1 $(37 \mathrm{mg})$ was subjected to preparative TLC. Compounds 1 (6 mg, $n$-heptane/AcOEt, $4: 6, R f=0.43)$ and $2(13 \mathrm{mg}, n$-heptane/AcOEt, $4: 6, R f=0.67)$ were obtained. Subfraction E2 $(118 \mathrm{mg})$ was rechromatographed on a silica gel column $(40-63 \mu \mathrm{m}, 5 \times 25 \mathrm{~cm})$ using $n$-heptane-AcOEt $(6: 4)$ to give 3 $(7 \mathrm{mg})$. Subfraction E3 was passed through silica gel with $n$-heptane/AcOEt $(60: 40)$ and purified by preparative TLC to afford $4(37 \mathrm{mg}, n$-heptane/ AcOEt, $1: 1, R f=0.38)$. Further repeated silica gel chromatography of fraction F with $n$-heptane/AcOEt $(55: 45)$ yielded $5(28 \mathrm{mg})$.

Compound 1: Colourless oil; $[\alpha]_{\mathrm{D}}^{25}+39.4^{\circ}\left(c=0.1, \mathrm{CH}_{2} \mathrm{Cl}_{2}\right)$; UV $(\mathrm{MeOH}): \lambda_{\max }(\log \varepsilon)=218(4.14) \mathrm{nm} ; \mathrm{IR}\left(\mathrm{CHCl}_{3}\right): v_{\max }=3472,1772,1715$, 1668, and $1642 \mathrm{~cm}^{-1}$; ${ }^{1} \mathrm{H}$ - and ${ }^{13} \mathrm{C}-\mathrm{NMR}$ (Table 1 ); HR-ESI-MS: $\mathrm{m} / \mathrm{z}$ $361.1651[\mathrm{M}+\mathrm{H}]^{+}\left(\right.$Calcd for $\left.\mathrm{C}_{20} \mathrm{H}_{25} \mathrm{O}_{6}: 361.1646\right)$.
Compound 2: Colourless oil, $[\alpha]_{\mathrm{D}}^{25}+37.3^{\circ}\left(c=0.1, \mathrm{CH}_{2} \mathrm{Cl}_{2}\right)$; UV $(\mathrm{MeOH}): \lambda_{\max }(\log \varepsilon)=215(4.37) \mathrm{nm} ; \mathrm{IR}\left(\mathrm{CHCl}_{3}\right): v_{\max }=2917,1769$ and $1708 \mathrm{~cm}^{-1} ;{ }^{1} \mathrm{H}$ - and ${ }^{13} \mathrm{C}$-NMR (Table 1); HR-ESI-MS: $\mathrm{m} / \mathrm{z} 343.1556$ $[\mathrm{M}+\mathrm{H}]^{+}$(Calcd for $\left.\mathrm{C}_{20} \mathrm{H}_{23} \mathrm{O}_{5}: 343.1549\right)$.

Compound 3: Colourless oil; $[\alpha]_{\mathrm{D}}^{25}+87.6^{\circ}\left(c=0.1, \mathrm{CH}_{2} \mathrm{Cl}_{2}\right)$; UV $(\mathrm{MeOH}): \lambda_{\max }(\log \varepsilon)=215(4.12) \mathrm{nm} ; \mathrm{IR}\left(\mathrm{CHCl}_{3}\right): v_{\max }=3544,1781,1718$, 1677 and $1629 \mathrm{~cm}^{-1}$; ${ }^{1} \mathrm{H}-$ and ${ }^{13} \mathrm{C}-\mathrm{NMR}$ (Table 1 ); HR-ESI-MS: $m / z$ $393.1917[\mathrm{M}+\mathrm{H}]^{+}$(Calcd for $\left.\mathrm{C}_{21} \mathrm{H}_{29} \mathrm{O}_{7}: 393.1922\right)$.

In Vitro Cytotoxicity The sulforhodamine $\mathrm{B}$ (SRB) assay against mouse neuroblastoma B104 was carried out according to the procedures by Skehan et al. ${ }^{9)}$

Acknowledgement This research was supported by a grant from the French government to Dr. Tabopda. The authors thank Drs. Julien Bouissac and Gerard Labourdette for technical assistance and also acknowledge the laser confocal facility service of the IBMP (Strasbourg, France).

\section{References}

1) Adjanohoun J. E., Aboubakar N., Dramane K., Ebot M. E., Ekpere J. A., Enow-Orock E. G., Focho D., Gbile Z. O., Kamanyi A., Kamsu K. J., Keita A., Mbenkum T., Mbi C. N., Mbiele A. L., Mbome I. L., Mubiru N. K., Nancy W. L., Nkongmeneck B., Satabie B., Sofowora A., Tamze V., Wirmum C. K., "Traditional Medicine and Pharmacopoeia, Contribution to Ethnobotanical and Floristic Studies in Cameroon," ed. by CNPMS, Porto-Novo, Benin, 1996, p. 85.

2) Tabopda K. T., Liu J., Ngadjui B. T., Luu B., Planta Med., 73, 376380 (2007).

3) Fuchino H., Koide T., Takahashi M., Sekita S., Satake M., Planta Med., 67, 647-653 (2000).

4) Banerjee S., Schmeda H. G., Castro V., Schuster A., Jakupovic J., Bohlmann F., Planta Med., 52, 29-32 (1986).

5) Zhang D., Haruna M., McPhail A. T., Lee K. H., Phytochemistry, 25 , 899-904 (1986).

6) Kupchan S. M., Aynehchi Y., Cassady J. M., Schnoes H. K., Burlingame A. L., J. Org. Chem., 34, 3867-3875 (1969).

7) But P. P. H., Hon P. M., Cao H., Chan T. W. D., Wu B. M., Mak T. C. W., Che C. T., Phytochemistry, 44, 113-116 (1997).

8) Siedle B., García-Piñeres A. J., Murillo R., Schulte-Mönting J., Castro V., Rüngeler P., Klaas C. A., Da Costa F. B., Kisiel W., Merfort I., J. Med. Chem., 47, 6042-6054 (2004).

9) Skehan P., Storeng R., Scudiero D., Monks A., McMahon J., Vistica D., Warren J. T., Bokesch H., Kenny S., Boyd R. M., J. Natl. Cancer Inst., 82, 1107-1112 (1990).

10) Pereira P. S., Dias D. A., Vichnewski W., Nasi A. M., Herz W., Phytochemistry, 45, 1445-1448 (1997).

11) Schorr K., Garcia-Pineres A. J., Siedle B., Merfort I., Da Costa F. B., Phytochemistry, 60, 733-740 (2002).

12) Kisiel W., Zielinska K., Phytochemistry, 57, 523-527 (2001). 